\title{
The Construction and Performance of Citizenship in Contemporary China
}

\author{
Carolyn L. Hsu, Jessica C. Teets, Reza Hasmath, Jennifer Y. J. Hsu \& Timothy \\ Hildebrandt
}

To cite this article: Carolyn L. Hsu, Jessica C. Teets, Reza Hasmath, Jennifer Y. J. Hsu \& Timothy Hildebrandt (2022): The Construction and Performance of Citizenship in Contemporary China, Journal of Contemporary China, DOI: $10.1080 / 10670564.2022 .2030993$

To link to this article: https://doi.org/10.1080/10670564.2022.2030993

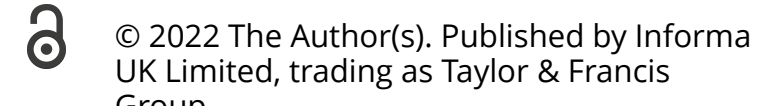
Group.

巴- Published online: 30 Jan 2022.

Submit your article to this journal 지

Q View related articles $\asymp$

View Crossmark data $\asymp$ 


\title{
The Construction and Performance of Citizenship in Contemporary China
}

\author{
Carolyn L. Hsu ${ }^{a}$, Jessica C. Teets ${ }^{b}$, Reza Hasmath, Jennifer Y. J. Hsu ${ }^{d}$ \\ and Timothy Hildebrandt ${ }^{\mathrm{e}}$
}

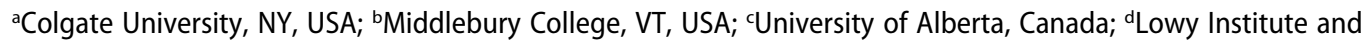
University of New South Wales, Australia; 'London School of Economics and Political Science, UK

\begin{abstract}
Citizenship education has been an explicit part of the universal education system in contemporary China. Using data from an original nationwide survey conducted in 2018, this study tests the hypothesis that the longer the intensity of exposure to citizenship education, the more citizens are influenced by a state-led conception of citizenship characterized by passive obedience and loyalty to the state. The study finds mixed results in that citizenship education is effective at lower educational levels, but at higher levels it is not only less effective, but instead may foster (or at minimum, does not deter) more active conceptions of citizenship.
\end{abstract}

\section{Introduction}

Most regimes devote resources to constructing 'good' or 'model' citizens through education about the 'legal and emotive tie between the state and the citizen', ${ }^{1}$ but these efforts vary. For example, nations such as the Netherlands and Bulgaria require one to two years of citizenship education, whereas France and Portugal require more than nine years. ${ }^{2}$ The goal of this education also varies, ranging from teaching about citizen rights and responsibilities ${ }^{3}$ to creating regime loyalty. ${ }^{4}$ In authoritarian regimes, the latter goal is predominant. For example, in a study of citizenship education in Myanmar, Treadwell characterizes this as teaching students about 'moral values relating to discipline and obedience' to authorities. ${ }^{5}$ As Geddes and Zaller ${ }^{6}$ note, mainstream models predict that exposure to this education indoctrinates citizens. However, scholars debate the effectiveness of this education with the type of education intervention, teacher training, and length of exposure as factors that might impact effectiveness. ${ }^{7}$

CONTACT Carolyn L. Hsu chsu@colgate.edu Department of Sociology and Anthropology, Colgate University 13 Oak Drive, Hamilton, NY, 13346, USA; Timothy Hildebrandt T.R.Hildebrandt@lse.ac.uk $\mathbf{E}$ London School of Economics and Political Science, UK

${ }^{1}$ Cheryl Hendricks, 'The national question, ethnicity, and the state: some insights on South Africa', in The State and Democracy in Africa, ed. George Nzongola-Natalaja and Margaret C. Lee (Harare: AAPS Books, 1997), pp. 104-13.

'European Union's Education, Audiovisual and Culture Executive Agency, 'International comparison on citizenship education', European Commission EACEA Report (2012).

${ }^{3}$ Bryan S. Turner and Peter Hamilton, Citizenship: Critical Concepts (London: Routledge, 1994).

${ }^{4}$ Tarik M. Yousef, 'Development, growth and policy reform in the Middle East and North Africa since 1950', Journal of Economic Perspectives 18(3), (2004), pp. 91-115; and Jae-Cheon Lim and Ho-Yeol Yoo, 'Institutionalization of the Cult of the Kims: its implications for North Korean political succession', The Korean Journal of Defense Analysis 22(3), (2010), pp. 341-54.

${ }^{5}$ Brooke A. Treadwell, 'Teaching citizenship under an authoritarian regime: a case-study of Burma', ProQuest LLC (2013).

${ }^{6}$ Barbara Geddes and John Zaller, 'Sources of popular support for authoritarian regimes', American Journal of Political Science 33 (2), (1989), pp. 319-347.

${ }^{7}$ Murray Print et al., Youth electoral study-report 1: enrolment and voting, 2004. Accessed January 6, 2022. https://www.aec. gov.au/About_AEC/Publications/files/youth-study/youth_electoral_study_01.pdf.

(c) 2022 The Author(s). Published by Informa UK Limited, trading as Taylor \& Francis Group.

This is an Open Access article distributed under the terms of the Creative Commons Attribution-NonCommercial-NoDerivatives License (http:// creativecommons.org/licenses/by-nc-nd/4.0/), which permits non-commercial re-use, distribution, and reproduction in any medium, provided the original work is properly cited, and is not altered, transformed, or built upon in any way. 
In this context, the study tests the relationship between exposure and internalization of citizenship education in the People's Republic of China (PRC), the world's largest authoritarian state. Citizenship education was important enough to the Communist Party of China (CPC) that it was implemented into the universal education system by 1957 , only eight years after the Party took over the country. Although the curriculum has been revised over the decades, sometimes substantially, its central message has always been that good citizenship is manifested through loyalty and obedience to the CPC. Chinese citizenship education encourages a passive, submissive relationship to the state. One way to measure the effectiveness of this education is to see whether those exposed to more of it are more likely to have internalized its message. Chinese citizenship education begins in primary school and continues through the tertiary level. ${ }^{8}$ People with higher levels of education, then, have been exposed to more Chinese citizenship education.

Using data from an original nationwide survey conducted in late 2018, this study explores whether increased years of exposure to Chinese citizenship education make subjects more or less likely to agree with this version of good citizenship promoted by the national curriculum. What is found is that, paradoxically, the more years of citizenship education a person endures, the less likely they are to endorse the Chinese state curriculum's concept of citizenship. Furthermore, respondents who receive a high school education or less are more likely to agree with the state's version of good citizenship than those who have more years of schooling. On average, $38.1 \%$ of respondents with a high-school education or less selected that good citizens 'support the Party' as their first option, while only $26.0 \%$ of those with university education or higher did. However, after secondary education, our results suggest that the more years of citizenship education a person receives, the less likely they were to agree with this state-led version of citizenship: $28.0 \%$ of those with higher education selected this as their last option out of six choices. Respondents with more than a high school education selected a more active definition of citizenship, such as 'good citizens use their expertise to try to solve problems in society': $30.1 \%$ versus $17.8 \%$ of those with high-school or less. Although this was not the goal of the curriculum, greater exposure to citizen education is positively correlated with a more active and participatory view of citizenship.

Despite the Party's recent emphasis on citizenship education, more exposure actually results in less internalization of the state's message. The study finds that citizenship education is effective at lower educational levels, but at higher levels, this education is less effective and fails to deter more active conceptions of citizenship. Although the survey does not provide recourse to fully explain the mechanisms underlying this argument, studies from other authoritarian states reveal that citizens at high education levels have more exposure to indoctrination; but also tools to resist, such as critical thinking skills or access to alternative information. ${ }^{9}$ These findings show that the effectiveness of citizenship education declines above the secondary level, thus the Party should redesign the curriculum, or invest in new tools such as Party-mobilized volunteering that evidence higher levels of student satisfaction and support. ${ }^{10}$

\footnotetext{
${ }^{8} \mathrm{Jie}$ Lu, 'Ideological and political education in China's Higher Education', East Asian Policy 9(2), (2017), pp. 78-91; and Gang Guo, 'Party recruitment of college students in China', Journal of Contemporary China 14(43), (2007), pp. 371-93.

${ }^{9}$ Geddes and Zaller, 'Sources of Popular Support for Authoritarian Regimes'.

${ }^{10}$ Jerome Doyon, 'Low-cost corporatism: the Chinese communist youth league and its sub-organisations in post-Mao China', China Perspectives 2, (2019), p. 39.
} 


\section{Theoretical Framework}

\section{Constructing Citizenship in Authoritarian Regimes}

Most of the foundational literature looking at the construction of citizenship in authoritarian regimes extrapolates from post-colonial or post-conflict situations. ${ }^{11}$ The findings generally focus on the tools utilized by authoritarian regimes to socialize citizens and foster feelings of community identity. ${ }^{12}$ The autocrat's logic behind citizenship construction projects is mostly functional, in that, creating 'ideal citizens' encourages citizens to act in similar ways that legitimate and support the autocrat's rule. ${ }^{13}$ However, Jones challenges the conception of the autocrat narrowly focused on political survival, and argues that autocrats' personal experiences in the West as young individuals supplied them with stylized ideas about how contemporary productive peoples ought to act, and how their own cultures underperform. ${ }^{14}$ Regardless of the logic behind these citizenship construction projects, the primary mechanism whereby states construct model citizens is citizenship education. ${ }^{15} \mathrm{~A}$ vast literature exists on the ability of education to shape individuals' beliefs. While it is not feasible to review all the literature here, ${ }^{16}$ in general, the literature posits that education has a causal influence on individual attitudes and beliefs. ${ }^{17}$

In authoritarian states, research offers some evidence that citizenship education effectively teaches individuals to be more supportive and less critical of ruling regimes. ${ }^{18}$ For example, university students in mainland China, who are subjected to a more deliberately patriotic and nationalistic citizenship education curriculum, report higher levels of patriotism and nationalism than their Hong Kong counterparts, who receive a more depoliticized version of citizenship education. ${ }^{19}$ Research further reveals that in authoritarian states, more years of education does correlate, to some extent, with higher levels of regime support. ${ }^{20}$ Namely, the more years a person spends in formal schooling, the more citizenship education they receive; thus, increasing their exposure to state messaging. ${ }^{21}$

Notwithstanding this overall trend, there is also evidence that citizenship education, in practice, may lose its effectiveness at higher levels of education. Geddes and Zaller, ${ }^{22}$ using 1970s data from Brazil, found that the relationship between more years of education and regime support is curvilinear. People with the fewest years of education (less than five) report lower levels of regime support than those who had attended at least some years of middle school or high school; however, this

\footnotetext{
${ }^{11}$ See Reinhard Bendix, Nation-building and Citizenship: Studies of our Changing Social Order (London: Routledge, 2017); Ernest Gellner, Nations and Nationalism (Ithaca, NY: Cornell University Press, 1983); and Eric J. Hobsbawm, Nations and Nationalism since 1780: Programme, Myth, Reality (Cambridge: Cambridge University Press, 1990).

${ }^{12}$ Jeffrey Herbst, State and Power in Africa: Comparative Lessons in Authority and Control (NJ: Princeton University Press, 2002).

${ }^{13}$ Ruby Dagher, 'Legitimacy and post-conflict state-building: the undervalued role of performance legitimacy', Conflict, Security and Development 18(2), (2018), pp. 85-111; Herbst, State and Power in Africa.

${ }^{14}$ Calvert W. Jones, 'Seeing like an autocrat: liberal social engineering in an illiberal state', Perspectives on Politics 13(1), (2015), pp. 24-41; and Calvert W. Jones, Bedouins into Bourgeois: Remaking Citizens for Globalization (Cambridge: Cambridge University Press, 2017).

${ }^{15}$ Michael Mann, 'Ruling class strategies and citizenship', Sociology 21(3), (1987), pp. 339-54.

${ }^{16}$ For a good summary, see Davide Cantoni et al., 'Curriculum and ideology', Journal of Political Economy 125(2), (2017), pp. 33892.

${ }^{17}$ Irma Clots-Figueras and Paolo Masella, 'Education, language and identity', Journal of Economics 123(570), (2013), pp. F332-57; Willa Friedman et al., 'Education as liberation?' Economica 83(329), (2015), pp. 1-30; Paolo Freire, Pedagogy of the Oppressed (New York: Continuum, 1970); Seymour M. Lipset, 'Some social requisites of democracy: economic development and political legitimacy', American Political Science Review 53(1), (1959), pp. 69-105; and John R. Lott, 'Public schooling, indoctrination, and totalitarianism', Journal of Political Economy 107(6), (1999), pp. S127-57.

${ }^{18}$ Cantoni et al., 'Curriculum and ideology'.

${ }^{19}$ Gregory P. Fairbrother, Toward Critical Patriotism (Hong Kong: Hong Kong University Press, 2003).

${ }^{20}$ Geddes and Zaller, 'Sources of popular support for authoritarian regimes'; and John J. Kennedy, 'Maintaining popular support for the Chinese Communist Party: the influence of education and the state-controlled media', Political Studies 57(3), (2009), pp. 517-36.

${ }^{21}$ Although in Zimbabwe, another authoritarian context, mass education reform in 1980 led to decreased support for the ruling party and greater dissatisfaction of government performance. See Kevin Croke et.al., 'The effect of education on political participation in electoral authoritarian regimes: evidence from Zimbabwe', Zimbabwe Education 9 (2014), pp. 1-60.

${ }^{22}$ Geddes and Zaller, 'Sources of popular support for authoritarian regimes'.
} 
support diminishes as education levels increase. Zhang and Fagan's longitudinal study of university students finds some evidence that citizen education promotes regime support. ${ }^{23}$ However, Kennedy's results are more similar to Geddes and Zaller's ${ }^{24}$ Chinese citizens who had graduated from middle and high school were more supportive of the state than those with less education. But those who graduated from university reported lower levels of regime support than high school/ middle school graduates. Robinson found that the mass expansion of higher education in Chinawhere tertiary enrollments increased from $20 \%$ for those ages 18 to 22 in 2004 to $45.7 \%$ in $2017^{25}$ - 'substantially and significantly decreased regime support among the university-aged cohort". ${ }^{26}$ These studies suggest, in sum, that the relationship between education and regime support rises, but eventually reverses, with higher levels of education.

Why would too much citizenship education potentially backfire? One could argue that university students receive more state benefits than those with less schooling, and the provision of education and other public goods should engender regime support. ${ }^{27}$ Perhaps the problem lies in the quality of the citizenship education itself. Huang's research reveals that political propaganda loses its effectiveness when it is done poorly; clumsy and crude 'hard propaganda' can actually worsen citizens' views of the regime because they find the arguments unpersuasive. ${ }^{28}$ Zhang and Fagan found that university students in China were not impressed with the teaching quality of citizenship education courses at the tertiary level, which influenced the effectiveness of the content. ${ }^{29}$ Citizenship education may be taught poorly at the tertiary level in China, or these older students may have higher standards for teaching than primary and middle school pupils do. At the highest levels of education, individuals are taught to think more critically and are exposed to alternative viewpoints, and may be able to see through the state's messaging. Recent studies find younger Chinese citizens from urban areas are more critical of the state than their older or more rural compatriots. ${ }^{30}$ This may be due to the fact this demographic has the highest average level of educational attainment in China, with a disproportionate number of university graduates compared to other age groups. ${ }^{31}$

\section{Views of Good Citizenship in China}

Empirical research in the PRC reveals a range of views about what constitutes good citizenship among the populace, although these studies are not necessarily able to show either the prevalence of each view within the population or the mechanisms that lead a person to hold one view over another. ${ }^{32}$ For example, Distelhorst and Fu look at Chinese public complaint letters, which reveal a variety of ways of performing citizenship, ranging from enacting abject subjecthood to insisting upon legal rights. ${ }^{33}$ The three most common versions of good citizenship supported by this scholarship are socialist citizenship, suzhi citizenship, and legal citizenship.

\footnotetext{
${ }^{23}$ Chong Zhang and Catherine Fagan, 'Examining the role of ideological and political education on university students' civic perceptions and civic participation in Mainland China: some hints from contemporary citizenship theory', Citizenship, Social and Economics Education 15(2), (2016) pp. 117-42.

${ }^{24}$ Kennedy, 'Maintaining popular support for the Chinese Communist Party'.:

${ }^{25}$ Darrel Robinson, 'Higher education and support for authoritarian rule: evidence from the expansion of tertiary schooling in China' (unpublished paper, Department of Government, Uppsala University, 2019), p. 25.

${ }^{26}$ Robinson, 'Higher education and support for authoritarian rule', p. 23.

${ }^{27}$ See for example, Bruce Dickson, The Dictator's Dilemma: The Chinese Communist Party's Strategy for Survival (New York: Oxford University Press, 2106)

${ }^{28}$ Haifeng Huang, 'The pathology of hard propaganda', Journal of Politics 80 (3), (2018) pp. 1034-38.

${ }^{29}$ Zhang and Fagan, 'Examining the role of ideological and political education on university students'.

${ }^{30}$ Eaton and Hasmath, 'Economic legitimation in a new era'.

${ }^{31}$ Donald J. Treiman, 'Trends in educational attainment in China', Chinese Sociological Review 45(3), (2013), pp. 3-25.

${ }^{32}$ Sophia Woodman and Zhonghua Guo, 'Introduction: practicing citizenship in contemporary China', Citizenship Studies 21(7), (2017), pp. 737-54; Carolyn L. Hsu, Creating MARKET SOCIALism (Durham: Duke University Press, 2007); Greg Distelhorst and Diana Fu, 'Performing authoritarian citizenship: public transcripts in China', Perspectives on Politics 17(1), (2019), pp. $106-21$.

${ }^{33}$ Distelhorst and Fu, 'Performing authoritarian citizenship'.
} 
Socialist citizenship assumes that the citizen is subordinate and dependent upon the state, which holds a paternalistic position over the people. ${ }^{34}$ It provides care and resources, and the citizen responds with adoration and submission. Socialist citizenship posits a passive citizen, who allows the state to hold all significant decision-making power. However, socialist citizenship can be used to argue that citizen loyalty is conditional, predicated on the party-state's ability to fulfill its promises such as providing basic welfare to its citizens. ${ }^{35}$ This version of citizenship assumes a relationship of reciprocity between the state and its citizens. If the state fails to provide for its citizens' needs, or if political officials act greedy and corrupt rather than serving the people, then citizens can threaten to withdraw their loyalty. ${ }^{36}$ Yet this situation is supposed to be the exception, not the norm, and citizens should only have to invoke this threat under dire and unusual circumstances.

Similar to socialist citizenship in China, in suzhi citizenship, citizens believe that they may make certain demands of the state, and if the state fails to hold up its end of the bargain, it loses its political legitimacy. The difference lies in what kind of services citizens can expect the state to provide. Suzhi can be translated as 'quality'. Instead of the state acting as a paternalistic provider that takes care of basic needs, suzhi citizenship expects the state to provide its citizens with high-quality conditions for self-development. ${ }^{37}$ Suzhi ideology became a dominant narrative in early twenty-first century China. ${ }^{38}$ It was first used to promote the now defunct one-child policy in the 1980s, and it became the key operating term for education reform in the late 1990s (suzhi jiaoyu). ${ }^{39}$ Suzhi citizenship permits citizens to be relatively apolitical, focusing primarily on their own development into capitalistic workers and consumers.

However, suzhi citizenship also opens the door for citizens to have a more active role, to engage in some forms of rightful resistance and social entrepreneurship. ${ }^{40}$ In contrast to socialist citizenship, it allows a citizen to imagine an active role even under ordinary circumstances. Namely, citizens who bring low-quality conditions to the attention of political leaders should not only be able to expect a response, but also they could plausibly claim that they are doing the state a favor. Citizens who organize to solve social problems on their own are also doing a good by contributing to the overall improvement of the nation; thus, justifying many forms of citizen organization and mobilization. ${ }^{41}$ Since suzhi ideology claims that those who are more 'developed' are higher-quality people, and since 'development' is conflated primarily with education, active suzhi citizenship is more accessible to people with higher levels of education than lower ones. ${ }^{42}$

\footnotetext{
${ }^{34}$ Distelhorst and Fu, p. 114.

${ }^{35}$ See Wing-Wah Law, 'Citizenship, citizenship education, and the state in China in a global age', Cambridge Journal of Education 36(4), (2006), pp. 597-628.

${ }^{36}$ Carolyn L. Hsu 'Political narratives and the production of legitimacy: the case of corruption in post-Mao China', Qualitative Sociology 24(1), (2001), pp. 25-54; Eaton and Hasmath, 'Economic legitimation in a new era'; Bruce Gilley, 'Legitimacy and institutional change: the case of China', Comparative Political Studies 41(3), (2008), pp. 259-84; and Elizabeth Perry, 'The populist dream of Chinese democracy', Journal of Asian Studies 74(4), (2015), pp. 903-15.

${ }^{37}$ Carolyn L. Hsu, Social Entrepreneurship and Citizenship in China: The Rise of NGOs in the PRC (London: Routledge, 2017); Delia Lin, Civilising Citizens in Post-Mao China: Understanding the Rhetoric of Suzhi (London: Routledge, 2017); and Rachel Murphy, 'Turning peasants into modern Chinese citizens', The China Quarterly 177, (2004), pp. 1-20.

${ }^{38}$ Ann Anagnost, 'The Corporeal Politics of Quality (suzhi)', Public Culture 16(2), (2004), pp. 189-208; C. Hsu, Creating Market Socialism; Andrew Kipnis, 'Neoliberalism reified: Suzhi discourse and tropes of neoliberalism in the People's Republic of China', The Journal of the Royal Anthropological Institute 13(2), (2007), pp. 383-400; and Yan Hairong, 'Neoliberal governmentality and neohumanism: organizing Suzhi/value flow through labor recruitment networks', Cultural Anthropology 18(4), (2003), pp. 493523.

${ }^{39}$ Wing-Wah Law, 'Globalization, national identity, and citizenship education: China's search for modernization and a modern Chinese citizenry', Frontiers of Education in China 8(4), (2013), pp. 596-627.

${ }^{40} \mathrm{Hsu}$, Social Entrepreneurship and Citizenship in China.

${ }^{41}$ Carolyn L. Hsu. 'How the ideology of "quality" protects civil society in Xi Jinping's China,' China Information 35(1), (2021), pp. 2545.

${ }^{42} \mathrm{Hsu}$, Social Entrepreneurship and Citizenship in China.
} 
Finally, legal citizenship insists that both political officials and citizens are equal under the law. ${ }^{43}$ As a result, citizens have the right to criticize state actors if they violate legal policies; it is a form of rightful resistance. ${ }^{44}$ Under Xi Jinping, the official emphasis on the the 'rule of law' (yifa zhiguo) and top-down policy centralization has only intensified. ${ }^{45}$ Unlike socialist and suzhi citizenship, legal citizenship focuses less on the Communist Party/state, and more on the rights of the individual. This discourse has empowered citizens to invoke the law when they want to hold state actors accountable, whether via formal complaints, petitions, protests, or direct lawsuits. $^{46}$

\section{Citizenship Education in China}

Citizenship education became an explicit part of the Chinese universal education system in 1957, when Mao Zedong declared: 'Our educational policy must enable everyone who receives an education to develop morally, intellectually and physically and become a worker with both socialist consciousness and culture'. ${ }^{47}$ In 1958, political education first became a separate subject for secondary school students. ${ }^{48}$ During the Cultural Revolution (1966-76), the education bureaucracy lost control over political education, but in the post-Mao period, Deng Xiaoping reinstated citizenship education in a more comprehensive fashion in the $1980 \mathrm{~s} .{ }^{49}$ Citizenship education has remained a priority for the state in the twenty-first century. ${ }^{50}$ In 2004 , the State Council proclaimed: 'School is the primary channel for transmitting ideological and moral education to young people. ${ }^{.51}$ In 2019 , the Communist Party of China (CPC) reinforced this stance by stating:

In order to build socialism, both now and in the future, we must cultivate the patriotism of students ... the spirit of patriotism should infuse the entire curriculum, and patriotism education should be promoted in the classroom, in teaching materials, and in hearts and minds. ${ }^{52}$

The curriculum used in Chinese citizenship education has carried different names over the years, including 'moral education', 'moral character education', 'patriotic education', and 'citizenship education. ${ }^{53}$ The content has been revised multiple times over the decades. ${ }^{54}$ Yet through its

\footnotetext{
${ }^{43}$ Distelhorst and Fu, p. 113.

${ }^{44}$ Kevin J. O'Brien, 'Rightful resistance revisited', Journal of Peasant Studies 40(6), (2013), pp. 1051-62; Kevin J. O'Brien and Lianjiang Li, Rightful Resistance in Rural China (Cambridge: Cambridge University Press, 2006).

${ }^{45}$ Baijie An, 'Party to have stronger rule of law role', China Daily, August 25, 2018, Accessed January 6, 2021. https://www. chinadaily.com.cn/a/201808/25/WS5b808f63a310add14f387b56.html; and Jessica C. Teets, Reza Hasmath, and Orion A. Lewis, 'The incentive to innovate? The behavior of policymakers in China', Journal of Chinese Political Science 22(4), (2017), pp. 505-17.

${ }^{46}$ Rachel E. Stern, 'Activist lawyers in post-tiananmen China', Law and Social Inquiry 42(1), (2016), pp. 234-51; Margaret Y. K. Woo, 'Conclusion: Chinese justice from the bottom up' in Chinese Justice: Civil Dispute Resolution in Contemporary China, ed. Margaret Y. K. Woo and Mary E. Gallagher (Cambridge: Cambridge University Press, 2011), pp. 380-402; and Margaret Y. K. Woo, 'Court reform with Chinese characteristics', Washington International Law Journal 27(1), (2017), p. 241.

${ }^{47}$ Mao Zedong, 'On the correct handling of contradictions among the people', in Selected Readings from the Works of Mao TseTung 1926-1963 (Honolulu: University Press of the Pacific, 2001), pp. 432-79.

${ }^{48}$ Law, 'Globalization, national identity, and citizenship education'.

${ }^{49}$ Zhang and Fagan, 'Examining the role of ideological and political education on university students'; and Stanley Rosen, 'Education and the political socialization of Chinese youths', in Education and Social Change in the People's Republic of China, ed. John N. Hawkins (New York: Praeger, 1983), pp. 310-34.

${ }^{50}$ Zhang and Fagan, 'Examining the role of ideological and political education on university students'; and Ping Tan, 'Dangdai daxuesheng gongmin jiaoyu de wenti yu duice [Problems and strategies of civic education of contemporary college students]', Guangxi Shifan Daxue Xuebao (Zhexue shehui kexue ban) [Journal of Guangxi Normal University (Social Sciences)] 1, (2013), pp. 165-67.

${ }^{51}$ Cantoni et al., 'Curriculum and ideology'.

52 新时代爱国主义教育实施纲要 (Outline for the implementation of patriotic education for the new era)', Central Committee of the Communist Party of China, November 13, 2019, Accessed January 6, 2022. trans. C.L. Hsu. http://politics.people.com.cn/ n1/2019/1113/c1001-31451633.html.

${ }^{53}$ Law, 'Globalization, national identity, and citizenship education', p. 608.

${ }^{54}$ Thomas K. Tse, 'Creating good citizens in China: comparing grade 7-9 school textbooks, 1997-2005', Journal of Moral Education 40(2), (2011), pp. 161-80. See Reza Hasmath, 'The education of ethnic minorities in Beijing', Ethnic and Racial Studies 34(11), (2011), pp. 1835-54; and Suzanne Pepper, 'Chinese education after Mao: two steps forward, two steps back, and begin again?', The China Quarterly 81, (1980), pp. 1-65.
} 
many iterations over the years, Chinese citizenship education has always taught a passive form of socialist citizenship, where good citizenship is equated loyalty and obedience to the Chinese Communist Party. ${ }^{55}$ As Wing-Wah Law explains, all the different terms and curricula 'served a single purpose: to socialize people (including students) into the norms, values, and ideologies deemed acceptable to and prescribed by the CPC-led state'. ${ }^{56}$ Therefore socialist citizenship, rather than suzhi or legal citizenship, has been the dominant message of Chinese citizenship education.

However, it is possible to find aspects of suzhi and legal citizenship promoted in Chinese citizenship education in secondary themes, especially in recent decades. Beginning in the 1980s, under Deng Xiaoping, the goal of education became to create citizens who had the skills and knowledge to implement the new market socialist reforms and compete on the global economy. To that end, citizenship education began to teach students that good citizens were those who could compete well in the international economy and that education was the key to this success. ${ }^{57}$ This theme became more explicit in the late 1990s, with the 'suzhi jiaoyu' or 'quality education' reforms, since they promoted the idea that students needed to raise their level of suzhi, or quality to serve China well. ${ }^{58}$ In 2001, new educational reforms promoted 'active participation in practice, critical thinking, collaborative exploration, searching for and processing information, and acquiring new knowledge, problem-solving, communicating, and collaborating. ${ }^{159}$ However, Chinese citizenship education has never taught students that good citizens ever organize independently of the party-state to solve social problems or transform society, much less that they use contentious politics to rightfully resist and criticize party-state officials. ${ }^{60}$ Zhang and Fagan find that ' ... party-related study and activities are the only kinds of participation which are clearly defined and greatly encouraged by the curriculum and the university. ${ }^{61}$

In the 2000s, Chinese citizenship education has increased its emphasis on legal rights, a potential foundation for legal citizenship. Textbooks published in 2003 through 2005, inform students that they have rights under the law. ${ }^{62}$ Good citizens, according to this curriculum, do not just abide by the law, but instead, they should utilize the law in the service of the nation; for example, by making suggestions to the state and monitoring the behavior of others. ${ }^{63}$ Between 2004 and 2010, a new curriculum (the '8th Curriculum Reform') was introduced to high school students with new sections on political participation. This included discussions on how political decision-making reflects the will of the people, explaining the processes of democratic elections in villages and urban resident committees, and describing the channels through which people can voice their opinions. ${ }^{64}$ Yet, it is important to emphasize that even when the curriculum does focus on legal rights and political participation, it still stresses the supremacy of the Communist Party. Any legal rights that a citizen enjoys are granted by the benevolence of the Party, and not be used to hold the Party accountable. The only forms of political participation described are limited to Party-created mechanisms such as local elections. ${ }^{65}$

The central message of Chinese citizenship education is more compatible with socialist citizenship: a story where a paternalistic state cares for loyal and obedient subjects. Although students are now encouraged to develop themselves to compete in the global marketplace, the curriculum

\footnotetext{
${ }^{55}$ Tse, 'Creating good citizens in China'; and Law, 'Citizenship, citizenship education, and the state in China'.

${ }^{56}$ Law, 'Globalization, national identity, and citizenship education', p. 608.

${ }^{57}$ Law, 'Citizenship, citizenship education, and the state in China'.

${ }^{58}$ Delia Lin, Civilising Citizens in Post-Mao China: Understanding the Rhetoric ofSuzhi (London: Routledge, 2017); and Su-Yan Pan, 'Reframing citizenship education in Beijing', Oxford Review of Education 43(6), (2017), pp. 643-58.

${ }^{59}$ Law, 'Globalization, national identity, and citizenship education'.

${ }^{60}$ Pan, 'Reframing citizenship education in Beijing', p. 652.

${ }^{61}$ Zhang and Fagan, 'Examining the role of ideological and political education on university students', p. 138.

${ }^{62}$ Gregory P. Fairbrother, Toward Critical Patriotism (Hong Kong: Hong Kong University Press, 2003).

${ }^{63}$ Tse, 'Creating good citizens in China'.

${ }^{64}$ Cantoni et al., 'Curriculum and ideology'.

${ }^{65} \mathrm{Hu} \mathrm{Li}$ and Chanbao Tan, 'Chinese teachers' perceptions of the 'good citizen': a personally responsible citizen', Journal of Moral Education 46(1), (2017), pp. 34-45.
} 
makes it clear that it is the Party that leads the way to China's prosperity. ${ }^{66}$ Therefore, citizens should subsume their individual goals to the collective, socialist good, which means following the CPC's leadership. ${ }^{67}$ For decades, Chinese citizenship education has taught students that patriotic love of China is inextricably linked to loving, supporting and defending the Party, as well as obeying its directives. $^{68}$

Under Xi Jinping's rule, beginning in 2012, the connection between good citizenship and loyalty/ obedience to the Communist Party of China has only been strengthened. ${ }^{69}$ In contrast to previous leaders, Xi Jinping has more tightly controlled this curriculum to sustain Party leadership. Education is an important means to help students strengthen their fundamental understanding of China (dahao zhongguo dise) and to transplant 'red DNA' (hongse jiyin) in order to 'resist ideological infiltration'. ${ }^{70}$ Accordingly, citizenship education has been

given two specific political tasks - to strengthen the CPC leadership, fully implement its education policies, and ensure schools are strong bases of CPC support; and to cultivate students' love of the CPC, the nation, and its people, and their understanding of, identification with, and support for the state's political system. ${ }^{71}$

This connection between patriotism and loyalty to the Party was reiterated in 2019 when the Central Committee of the CPC declared:

the essence of patriotism is to love the country, to love the Party, and also to love socialism ... The only guaranteed way to realize the country's prosperity and power is to uphold the Party's leadership and adhere to the road of socialism with Chinese characteristics with strong faith and sincere emotions. ${ }^{72}$

In sum, citizenship education in China teaches a more state-centered form of socialist citizenship, where citizens follow the lead of the Communist Party, and this has only strengthened under $\mathrm{Xi}$ Jinping. ${ }^{73}$ Ultimately, socialist citizenship expects that citizens give the state, or more specifically the Communist Party, their loyalty and obedience in exchange for its paternalistic care. The bargain does imply that citizens could criticize the state if it fails to meet its responsibilities to them. After all, students learn that the downfall of the regimes that preceded the CPC was due to their failure to protect and care for the Chinese people. ${ }^{74}$ Yet the curriculum never explicitly acknowledges the possibility of CPC failure. Instead, it expects citizenship to be passive. Although citizens should actively develop themselves as capitalist competitors in the economic realm, in the realm of politics, they should be passive and submissive.

\section{Methodology}

This study tests the hypothesis that the longer the intensity of exposure to citizenship education, the more citizens are influenced by the state-led conception of citizenship outlined above. China is used as a case study since Xi Jinping's emphasis on the 'rejuvenation of the nation' includes constructing

\footnotetext{
${ }^{66}$ Law, 'Citizenship, citizenship education, and the state in China in a global age', p. 605.

${ }^{67}$ Kwok Wah Cheung and Suyan Pan, 'Transition of moral education in China: towards regulated individualism', Citizenship Teaching and Learning 2(2), (2006), pp. 37-50; and Pan, 'Reframing citizenship education in Beijing', p. 652. Li and Tan, 'Chinese teachers' perceptions of the 'good citizen', p. 41.

${ }^{68}$ Gregory P. Fairbrother, Toward Critical Patriotism (Hong Kong: Hong Kong University Press, 2003); Law, 'Citizenship, citizenship education, and the state in China in a global age'; and Law, 'Globalization, national identity, and citizenship education'.

${ }^{69}$ Minghua Zhong and Jian Zhang, 'Analysis of the citizenship education of China's Junior High School stage', Asian Education and Development Studies 4(2), (2015), pp. 190-203.

${ }^{70}$ Wing-Wah Law, 'The role of the state and state orthodoxy in citizenship and education in China', in The Palgrave Handbook of Citizenship and Education (London: Palgrave Macmillan, 2020), pp. 297-314.

${ }^{71} \mathrm{Law}$, 'The role of the state and state orthodoxy in citizenship and education in China'.

72،新时代爱国主义教育实施纲要(Outline for the implementation of patriotic education for the new era)', Central Committee of the Communist Party of China.

${ }^{73}$ See Kerry J. Kennedy, Gregory Fairbrother and Zhenzhou Zhao, eds., Citizenship Education in China: Preparing Citizens for the 'Chinese Century' (London: Routledge, 2013).

${ }^{74}$ Zheng Wang, 'National humiliation, history education, and the politics of recent memory', International Studies Quarterly 52(4) (Inte 2008), pp. 783-806.
} 
model citizens and officials, and this curriculum is mandated throughout all levels of the education system. Thus, China is an explicit example where conceptions of citizenship focusing on obedience are being emphasized and taught continuously throughout the education experience. Given this, the attendant expectation is that evidence from China should confirm this hypothesis. However, if citizens vary in their conceptions of citizenship, this weakens the notion that the authoritarian state can use citizenship education to effectively inculcate a state-led conception of citizenship.

\section{Survey Design and Measurement}

To test the hypothesis, the authors conducted the Civic Participation in China Survey (CPCS) in 2018 and leveraged individual-level data. Using stratified, random sampling techniques, CPCS 2018, conducted in October 2018, surveyed individuals in mainland China. IP addresses served as unique identifiers to ensure the same individual was not taking the survey more than once, reduce the potential for clustering amongst individuals and, promote a stratified, online ${ }^{75}$ sampling methodology. The survey obtained 2,022 respondents, of which 1,402 were determined to be valid responses. Validity was determined based on completeness, ${ }^{76}$ meaning that invalid surveys left one or more required questions incomplete.

The survey questions primarily focused on the subject's attitudes towards and experiences with volunteering and charitable giving (state-led and citizen-initiated). The survey also asked about the respondents' understanding of what it means to be a good citizen. It is plausible that the survey's focus on volunteerism and charitable giving may have affected the responses to the question about citizenship; however, very few respondents chose 'volunteer service and participation in charities' as an important component of citizenship. In order to avoid pressure to provide politically correct responses, the survey did not address particularly sensitive political topics, and falls well within the range of surveys that have been conducted in China in the past.

The survey utilized both multiple choice and ranking questions. Individual demographic information gathered by the survey included age, gender, number of children, city, and Communist Party membership. Socio-economic information collected in the survey included level of education, occupation, and household income. Some questions asked respondents to choose all answers that were true: for example, asking respondents to choose all types of volunteering in which they have participated. Others asked respondents to rank answer choices, such as the appropriate type of organization to solve social problems. For ranking questions, respondents would rank the choices from one to six in order of most important to least important.

Respondents age forty and up were removed from the analysis for two reasons. First, the Cultural Revolution interrupted citizenship education in China for many years, and the regular curriculum was not reinstated until the 1980s. Due to the uneven implementation of education during that time period, and since many people from that age group had schooling delayed, it is not clear what kind of citizenship education these respondents received. Second, our sample from that age group was very small, with only eight persons in the lowest educational group.

The remaining respondents numbered a total of 1,264 people and were divided into three groups by level of education. The low education group received lower middle-school education attainment or less. In previous studies, scholars assigned only those with a primary-school education or less to the lowest education category. However, in China, primary and middle school education is compulsory, and the nation has become increasingly successful at preventing students from dropping out during those years. In our sample, only 32 individuals (1.82\% of the sample) reported not completing

\footnotetext{
${ }^{75}$ Although there are concerns about using online surveys, such as the ability to have representative samples, many scholars argue that web-based surveys can be as reliable as face-to-face surveys, and might help collect information otherwise inaccessible in an authoritarian context. See Alicia D. Simmons and Lawrence D. Bobo, 'Can non-full-probability internet surveys yield useful data? A comparison with full-probability face-to-face surveys in the domain of race and social inequality attitudes', Sociological Methodology 45(1), (2015), pp. 357-87.

${ }^{76}$ It should be acknowledged that this standard, survey administration practice has the small potential to add bias in the results.
} 
Table 1. Distribution of demographic variables

\begin{tabular}{lccc}
\hline & & $N$ & $\%$ \\
\hline Gender & Male & 532 & 42.09 \\
Age & Female & 732 & 57.91 \\
& $18-22$ & 445 & 35.21 \\
City Tier & $23-29$ & 568 & 44.94 \\
& $30-39$ & 251 & 19.86 \\
Party Membership & 1 & 598 & 47.31 \\
& 2 & 191 & 15.11 \\
Volunteer & 3 & 475 & 37.58 \\
& Yes & 292 & 23.10 \\
Education & No & 972 & 76.90 \\
& Yes & 735 & 58.15 \\
& No & 529 & 41.85 \\
& Low: Middle School or Less & 151 & 11.95 \\
& Mid: High School & 259 & 20.49 \\
\end{tabular}

Table 2. Demographics based on level of educational attainment

\begin{tabular}{|c|c|c|c|c|c|}
\hline & & $\begin{array}{l}\text { Low: Middle School or Less } \\
151\end{array}$ & $\begin{array}{l}\text { Mid: High School } \\
259\end{array}$ & $\begin{array}{l}\text { High: University } \\
854\end{array}$ & $\begin{array}{l}\text { Total } \\
1264\end{array}$ \\
\hline \multirow[t]{2}{*}{ Gender } & Male & $\begin{array}{c}54 \\
(35.76 \%)\end{array}$ & $\begin{array}{c}111 \\
(42.86 \%)\end{array}$ & $\begin{array}{c}367 \\
(42.97 \%)\end{array}$ & 532 \\
\hline & Female & $\begin{array}{c}97 \\
(64.24 \%)\end{array}$ & $\begin{array}{l}148 \\
(57.14 \%)\end{array}$ & $\begin{array}{c}487 \\
(57.03 \%)\end{array}$ & 732 \\
\hline \multirow[t]{3}{*}{ Age } & $18-22$ & $\begin{array}{c}47 \\
(31.13 \%)\end{array}$ & $\begin{array}{l}112 \\
(43.24 \%)\end{array}$ & $\begin{array}{l}286 \\
(33.49 \%)\end{array}$ & 445 \\
\hline & $23-29$ & $\begin{array}{c}60 \\
(39.74 \%)\end{array}$ & $\begin{array}{c}90 \\
(34.75 \%)\end{array}$ & $\begin{array}{c}418 \\
(48.95 \%)\end{array}$ & 568 \\
\hline & $30-39$ & $\begin{array}{c}44 \\
(29.14 \%)\end{array}$ & $\begin{array}{c}57 \\
(22.01 \%)\end{array}$ & $\begin{array}{l}150 \\
(17.56 \%)\end{array}$ & 251 \\
\hline \multirow[t]{3}{*}{ City Tier } & 1 & $\begin{array}{c}46 \\
(30.46 \%)\end{array}$ & $\begin{array}{c}71 \\
(27.41 \%)\end{array}$ & $\begin{array}{c}481 \\
(56.32 \%)\end{array}$ & 598 \\
\hline & 2 & $\begin{array}{c}16 \\
(10.60 \%)\end{array}$ & $\begin{array}{c}32 \\
(12.36 \%)\end{array}$ & $\begin{array}{c}143 \\
(16.74 \%)\end{array}$ & 191 \\
\hline & 3 & $\begin{array}{c}89 \\
(58.95 \%)\end{array}$ & $\begin{array}{l}156 \\
(60.23 \%)\end{array}$ & $\begin{array}{l}230 \\
(26.93 \%)\end{array}$ & 475 \\
\hline \multirow[t]{2}{*}{ Communist Party Membership } & Yes & $\begin{array}{l}12 \\
(7.95 \%)\end{array}$ & $\begin{array}{c}44 \\
(16.99 \%)\end{array}$ & $\begin{array}{l}236 \\
(27.63 \%)\end{array}$ & 292 \\
\hline & No & $\begin{array}{l}139 \\
(92.05 \%)\end{array}$ & $\begin{array}{l}215 \\
(83.01 \%)\end{array}$ & $\begin{array}{l}618 \\
(72.37 \%)\end{array}$ & 972 \\
\hline \multirow[t]{2}{*}{ Volunteer } & Yes & $\begin{array}{c}48 \\
(31.79 \%)\end{array}$ & $\begin{array}{l}119 \\
(45.95 \%)\end{array}$ & $\begin{array}{l}568 \\
(66.51 \%)\end{array}$ & 735 \\
\hline & No & $\begin{array}{l}103 \\
(68.21 \%)\end{array}$ & $\begin{array}{l}140 \\
(54.05 \%)\end{array}$ & $\begin{array}{l}286 \\
(33.49 \%)\end{array}$ & 529 \\
\hline
\end{tabular}

Percentage of the sample is noted in parentheses; for example, 54 of 151 or $35.76 \%$ of respondents with low educational attainment were male.

middle school. The middle education group had graduated from high school but had not attended a four-year university, and the high education group had attended (or was currently attending) university. Tables 1 and 2 provide the basic demographic breakdown of our sample, including the level of educational attainment. The sample has slightly more respondents between the age of 2329 and contains mostly educated citizens who are not Party members. Due to potential sampling variances by educational attainment between our survey data and the general population (as reported in the National Bureau of Statistics of China's 2018 Statistical Yearbook) models were tested with both weighted and unweighted education variables. 


\section{Hypotheses and Models}

If citizenship education were effective, the expectation would be that the longer exposure to citizenship education will correlate with conceptions of citizenship that are more compatible with the curriculum, i.e. passive, state-led socialist citizenship. However, if the curvilinear model posited by Geddes and Zaller ${ }^{77}$ holds, one would predict that support for state-led versions of passive socialist citizenship would increase with years of education up through secondary school, and then decline for those with more years of tertiary education. Finally, the null hypothesis would be that education does not influence conceptions of citizenship, i.e. no relationship between the two variables.

In order to test these hypotheses, a question about citizenship was utilized, where survey respondents were asked to rank order six options for the following:

What type of citizen serves China the most? Please sort them from the category that contributes the most to the one that contributes the least. The option that you think is the most important should be ranked 1 and the least important option ranked 6.

(1) Citizens who support the Communist Party

(2) Citizens who develop their economy through business growth and/or entrepreneurship

(3) Citizens who contribute to the country through education, expertise, and high-quality skills

(4) Citizens who contribute to society through volunteer service and participation in charities

(5) Citizens who serve in government departments and actively understand the situation.

(6) Citizens who abide by-laws, rules, and regulations

Among these responses, options \#1, 5, and 6 best reflect the passive, state-led socialist citizenship promoted by Chinese citizenship education. Option \#1 directly reflects the central message of the curriculum: good citizenship equates to supporting the CPC. Option \#5 alludes to the logic at the heart of passive socialist citizenship, that Party and state officials are wiser than ordinary citizens are and therefore, deserve deference and submission. Legal conceptions of citizenship are more difficult to operationalize, although one can potentially expect that respondents choose option \# 6 as their first choice. To wit, respondents could be choosing this answer since they believe that all people are equal under the law (legal citizenship), or due to the fact they are assenting to a passive version of citizenship were obeying the law is all that is expected of citizens.

By contrast, options \# 2,3, and 4 describe more active versions of citizenship that are centered on the individual citizen rather than the CPC or state. They can be seen as leaning toward the most activist aspects of suzhi citizenship, where developed, high-quality citizens serve China according to their own direction, without necessarily needing guidance from the Party-controlled state.

This leads us to our hypotheses:

Hypothesis 1a: increasing exposure as measured by education attainment is correlated with state-led conceptions of citizenship (measured by responses \#1, 5 , and 6 )

Hypothesis $1 \mathrm{~b}$ : less exposure is correlated with more active conceptions of citizenship (measured by responses \#2, 3, and 4)

Hypothesis 2: education attainment is correlated to conceptions of citizenship in a curvilinear relationship, where low and high levels of education attainment correlate with active conceptions of citizenship, and mid-levels of education correlate with state-led conceptions

\footnotetext{
${ }^{77}$ Geddes and Zaller, 'Sources of popular support for authoritarian regimes'.
} 
To explore the relationship between education and perceptions of citizenship, both linear regression and multinomial logistic regression modeling were used. Linear regression was used to analyze the rating of a single response option, while multinomial regression tested the odds of selecting one option over another. Based on previous studies of citizenship education, gender, age, city tier, Communist Party membership, and participation in volunteer activities served as control variables.

\section{Results}

Hypothesis 1a predicting that increased exposure as measured by education attainment correlates with more passive, state-led conceptions of citizenship, is not supported. In fact, the higher the level of education, the lower the likelihood of respondents selecting option 1, 'citizens who support the Communist Party'. There is no evidence of the alternative hypothesis, $1 \mathrm{~b}$, that less exposure is correlated with more active conceptions of citizenship. Instead, it appears that higher levels of education increase the likelihood of respondents selecting option 3, which pertains to contributing to the 'country through education, expertise and high-quality skills'. The other responses were not statistically significant.

There is not complete support for hypothesis 2 that education attainment is correlated to conceptions of citizenship in a curvilinear relationship, where low and high levels of education attainment correlate with active conceptions of citizenship, and mid-levels of education correlate with state-led conceptions. High-levels of education do support more active conceptions of citizenship, but that low and middle levels support state-led conceptions of citizenship.

The linear regression models evaluate how level of education impacts the rating of a single response option. As illustrated in Table 3, education has a statistically significant effect on the ranking of option 1, in that an increase in level of education is associated with a lower ranking of this option, controlling for age, city, gender, Communist Party membership, and whether a respondent has volunteered. Specifically, an increase in education is associated with a 0.594 decrease in ranking $(p<0.001)$, when the education variable is weighted.

Education also has a statistically significant impact on the ranking of option 3. An increase in level of education is associated with a higher ranking of this option, controlling for age, city, gender, Communist Party membership, and whether a respondent has volunteered. An increase in education is associated with a 0.387 increase in ranking $(p<0.001)$, when the education variable is weighted.

These results were confirmed by the multinomial regression model reported in Table 4, which compared the odds of choosing different response options. The odds of selecting option 3 rather than option 1 as the respondent's top choice increased if they had higher educational attainment. The odds that a respondent in the middle education group selected option 3 rather than option 1 were 1.91 times that of a respondent in the low education group $(p=0.036)$. The odds that a respondent in the high education group made this selection were 4.02 times that of a respondent in the low education group $(p<0.001)$. In both the linear and multinomial regression models, the difference is especially noticeable between respondents with at least some tertiary (university) education, and those without.

As Tables 3 and 4 indicate, the level of education did not have a statistically significant impact on all response options for this question. Therefore, to supplement this analysis with robustness checks, and to further explore respondents' perceptions of citizenship, an analysis of how education impacted three other survey questions that may contribute to forming these perceptions was conducted (see Appendix Tables A1 - A3):

(1) Do you participate in volunteer activities?

(2) Does the government provide sufficient help to disadvantaged groups?

(3) What areas does the government need help from social organizations? 
Table 3. Linear regression analysis of 'what type of citizen serves China the most?'

\begin{tabular}{|c|c|c|c|c|}
\hline Variable & Coefficient (Unweighted) & Std. Err. & Coefficient (Weighted) & Std. Err. \\
\hline \multicolumn{5}{|l|}{ Support the Communist Party } \\
\hline Education & $0.472^{* * *}$ & 0.086 & $0.594^{* * *}$ & 0.035 \\
\hline Gender & $-0.577^{* * *}$ & 0.111 & $-0.832^{* * *}$ & 0.049 \\
\hline Age Group & -0.054 & 0.077 & $-0.096^{* *}$ & 0.031 \\
\hline City Tier & -0.242 & 0.162 & $-0.256^{* *}$ & 0.080 \\
\hline Tier 3 & -0.230 & 0.125 & 0.006 & 0.053 \\
\hline Communist Party Membership & $-0.601^{* * *}$ & 0.133 & $-0.654^{* * *}$ & 0.075 \\
\hline Volunteer Participation & $-0.239^{*}$ & 0.117 & $-0.660^{* * *}$ & 0.051 \\
\hline Constant & 3.001 & 0.294 & 3.045 & 0.092 \\
\hline \multicolumn{5}{|l|}{ Education and Expertise } \\
\hline Education & $-0.357^{* * *}$ & 0.052 & $-0.387^{* * *}$ & 0.025 \\
\hline Gender & $0.184^{*}$ & 0.070 & $0.173^{* * *}$ & 0.035 \\
\hline Age Group & -0.066 & 0.035 & $0.055^{*}$ & 0.022 \\
\hline City Tier & 0.109 & 0.105 & 0.059 & 0.058 \\
\hline Tier 3 & -0.070 & 0.078 & $-0.138^{* * *}$ & 0.038 \\
\hline Communist Party Membership & 0.140 & 0.083 & $0.115^{*}$ & 0.054 \\
\hline Volunteer Participation & $0.166^{*}$ & 0.073 & $0.483^{* * *}$ & 0.037 \\
\hline Constant & 3.371 & 0.174 & 3.097 & 0.068 \\
\hline \multicolumn{5}{|l|}{ Business and Entrepreneurship } \\
\hline Education & -0.003 & 0.066 & 0.051 & 0.029 \\
\hline Gender & $-0.291^{* *}$ & 0.086 & $-0.411^{* * *}$ & 0.041 \\
\hline Age Group & 0.017 & 0.060 & $0.145^{* * *}$ & 0.025 \\
\hline City Tier & 0.230 & 0.126 & $0.240^{* * *}$ & 0.066 \\
\hline Tier 3 & $0.288^{* *}$ & 0.097 & $0.147^{* *}$ & 0.044 \\
\hline Communist Party Membership & -0.098 & 0.103 & $-0.262^{* * *}$ & 0.062 \\
\hline Volunteer Participation & 0.047 & 0.091 & $-0.483^{* * *}$ & 0.042 \\
\hline Constant & 3.625 & 0.225 & 3.634 & 0.078 \\
\hline Volunteering and Charity & & & & \\
\hline Education & 0.075 & 0.058 & 0.006 & 0.025 \\
\hline Gender & 0.008 & 0.075 & $0.174^{* * *}$ & 0.036 \\
\hline Age Group & $0.141^{* *}$ & 0.052 & $0.099^{* * *}$ & 0.022 \\
\hline City Tier & -0.085 & 0.110 & $-0.142^{*}$ & 0.059 \\
\hline Tier 3 & 0.023 & 0.085 & $-0.096^{*}$ & 0.039 \\
\hline Communist Party Membership & 0.072 & 0.091 & $-0.123^{*}$ & 0.055 \\
\hline Volunteer Participation & -0.152 & 0.080 & $-0.112^{* * *}$ & 0.038 \\
\hline Constant & 3.544 & 0.197 & 3.782 & 0.069 \\
\hline Working for Government & & & & \\
\hline Education & -0.091 & 0.068 & $-0.074^{*}$ & 0.029 \\
\hline Gender & $0.314^{* * *}$ & 0.089 & $0.409^{* * *}$ & 0.041 \\
\hline Age Group & -0.013 & 0.062 & -0.014 & 0.025 \\
\hline City Tier & -0.019 & 0.130 & $-0.337^{* * *}$ & 0.067 \\
\hline Tier 3 & 0.194 & 0.100 & 0.059 & 0.044 \\
\hline Communist Party Membership & -0.091 & 0.107 & -0.080 & 0.063 \\
\hline Volunteer Participation & 0.094 & 0.094 & $0.043^{* * *}$ & 0.043 \\
\hline Constant & 4.076 & 0.232 & 4.109 & 0.079 \\
\hline Abides by Laws and Regulations & & & & \\
\hline Education & -0.096 & 0.084 & $-0.188^{* * *}$ & 0.034 \\
\hline Gender & $0.362^{* *}$ & 0.109 & $0.486^{* * *}$ & 0.046 \\
\hline Age Group & -0.050 & 0.076 & $-0.190^{* *}$ & 0.020 \\
\hline City Tier & -0.007 & 0.159 & $0.436^{* * *}$ & 0.077 \\
\hline Tier 3 & -0.205 & 0.123 & 0.035 & 0.050 \\
\hline Communist Party Membership & $0.577^{* * *}$ & 0.131 & $1.005^{* * *}$ & 0.069 \\
\hline Volunteer Participation & 0.142 & 0.115 & $0.549^{* * *}$ & 0.048 \\
\hline Constant & 3.384 & 0.285 & 3.334 & 0.083 \\
\hline
\end{tabular}

The positive coefficient results from the scale being from 1-6, with 6 being a 'lower' ranking even though it is a higher number; ${ }^{*} p<0.05,{ }^{* *} p<0.01$, and ${ }^{* * *} p<0.001$

It could be the case that respondents perform other active forms of citizenship in their daily lives. To test this, the interaction of education on volunteering was examined, and it was found that there was a statistically significant effect of level of education on participation in volunteer activities. Increased level of education was associated with higher rates of volunteering, controlling for gender, age, city, 
Table 4. Multinomial regression analysis of 'what type of citizen serves China the most?'

\begin{tabular}{|c|c|c|c|c|c|c|c|}
\hline $\begin{array}{l}\text { Top Choice Response } \\
\text { Option } \\
\text { (Base Response: 'Support the } \\
\text { Communist Party') }\end{array}$ & $\begin{array}{l}\text { Level of Education } \\
\text { (Base Response: Low } \\
\text { Education Group) }\end{array}$ & $\begin{array}{c}\text { Coefficient } \\
\text { (Unweighted) }\end{array}$ & $\begin{array}{l}\text { Odds } \\
\text { Ratio }\end{array}$ & $\begin{array}{l}\text { Std. } \\
\text { Err. }\end{array}$ & $\begin{array}{l}\text { Coefficient } \\
\text { (Weighted) }\end{array}$ & $\begin{array}{l}\text { Odds } \\
\text { Ratio }\end{array}$ & $\begin{array}{l}\text { Std. } \\
\text { Err. }\end{array}$ \\
\hline \multirow[t]{2}{*}{ Education and Expertise } & Mid Education Group & $0.65 *$ & 1.91 & 0.31 & $0.78 * * *$ & 0.17 & 0.11 \\
\hline & High Education Group & $1.40 * *$ & 4.02 & 0.28 & $1.72 * * *$ & 0.59 & 0.12 \\
\hline \multirow{2}{*}{$\begin{array}{c}\text { Abides by Laws and } \\
\text { Regulations }\end{array}$} & Mid Education Group & $0.52 *$ & 1.69 & 0.27 & $0.74 * * *$ & 0.09 & 0.10 \\
\hline & High Education Group & $0.69 * *$ & 2.00 & 0.25 & $0.92 * * *$ & 0.52 & 0.12 \\
\hline \multirow[t]{5}{*}{ Working for Government } & Mid Education Group & & & & $0.68^{* * *}$ & 1.97 & 0.14 \\
\hline & High Education Group & & & & $0.83 * * *$ & 2.29 & 0.17 \\
\hline & Other Response Optio & s (not statistica & signifi & int) & & & \\
\hline & Mid Education Group & 0.54 & 1.71 & 0.42 & & & \\
\hline & High Education Group & 0.65 & 1.92 & 0.39 & & & \\
\hline \multirow[t]{2}{*}{ Business and Entrepreneurship } & Mid Education Group & 0.27 & 1.31 & 0.44 & 0.19 & 0.21 & 0.15 \\
\hline & High Education Group & 0.48 & 1.62 & 0.40 & 0.21 & 0.23 & 0.17 \\
\hline \multirow[t]{2}{*}{ Volunteering and Charity } & Mid Education Group & 0.42 & 1.52 & 0.51 & $0.47^{* * *}$ & 0.60 & 0.18 \\
\hline & High Education Group & -0.04 & 0.96 & 0.49 & 0.27 & 0.31 & 0.24 \\
\hline
\end{tabular}

${ }^{*} p<0.05,{ }^{* *} p<0.01$, and ${ }^{* * *} p<0.001$

and Communist Party membership. Logistic regression modeling indicated that the odds that a respondent in the middle education group volunteered were 1.59 times that of a respondent in the low education group $(p=0.037)$. The odds that a respondent in the high education group volunteered were 3.90 times that of a respondent in the low education group $(p<0.001)$. This result supports our findings above.

Level of education statistically significantly impacted whether a respondent thought that the government provided sufficient help to disadvantaged groups $(p<0.10)$. Respondents with higher levels of education were less likely to agree with this question, controlling for gender, age, city, and Communist Party membership. Logistic regression modeling indicated that the odds that a respondent in the middle education group agreed with this statement were 0.87 times less that of a respondent in the low education group $(p=0.10)$. The odds that a respondent in the high education group agreed with this statement were 0.59 times less that of a respondent in the low education group $(p=0.007)$.

Finally, the level of education did not significantly impact which social organizations respondents identified as needing government support. These tests give the authors confidence that the relationship between education and conceptions of citizenship is supported regardless of how it is measured.

\section{Conclusion}

Since its inception, Chinese citizenship education has primarily taught a state-led conception of citizenship, whereby the relationship between citizen and state is one of devotion and obedience. Yet over the decades, the curriculum has adapted to include additional messages in response to changing national and global circumstances. Since the post-market reform era, the Party has been aware that it needs to create citizens that can compete successfully in the global economy. The vision of the ideal Chinese citizen has shifted somewhat from the enthusiastic, but submissive worker to the patriotic professional. ${ }^{78}$ Although patriotism in Chinese citizenship education has generally been defined as submitting to the Party and upholding its leadership, these additions to the curriculum have allowed an educated subsection of the population to redefine the term. For them, patriotism can mean professionalism, since (in their view) 'high quality' citizens contribute more to society than their

\footnotetext{
${ }^{78}$ Lisa M. Hoffman, Patriotic Professionalism in Urban China (Philadelphia: Temple University Press, 2010).

${ }^{79}$ Jennifer Y. J. Hsu, Carolyn L. Hsu, and Reza Hasmath, 'NGO strategies in an authoritarian context, and their implications for citizenship: the case of the People's Republic of China', Voluntas: International Journal of Voluntary and Nonprofit Organizations 28(3), (2017), pp. 1157-79.
} 
less well-educated peers. Thus, the rise of suzhi citizenship amongst educated people in China can potentially be the basis for more active citizenship, as educated middle-class urbanites argue that they have the status and expertise to advise political leaders or solve social problems on their own. ${ }^{79}$

This study reveals that students in China who receive citizenship education do not absorb it wholesale, but have the critical thinking skills and information necessary to select the definition of good citizenship that allows them to see themselves as good citizens. For those with university degrees, this means focusing on the ways that those with more education serve the nation in a more active conception, as opposed to the state-led version mandating obedience and loyalty.

China is used as a confirming case for the causal relationship between citizenship education and conception of good citizens, since citizenship is taught continuously throughout students' educational careers. If citizens vary in their conception of citizenship, or believe in a conception counter to the state's vision, this greatly weakens the causal argument of the state's ability to use education to construct citizenship. Contrary to this argument, hypothesis 1a predicting that increased exposure as measured by education attainment correlates with state-led conceptions of citizenship, is not supported. In fact, higher education levels reduce the likelihood of respondents selecting the option which claims that good citizenship is defined by supporting the Communist Party. There is no evidence of the alternative hypothesis $1 \mathrm{~b}$, that less exposure is correlated with more active conceptions of citizenship. Instead, higher levels of education increase the likelihood of respondents selecting option 3 about contributing to the country directly through one's education, expertise and high-quality skills. Finally, there is not complete support for hypothesis 2, that education attainment is correlated to conceptions of citizenship in a curvilinear relationship, where low and high levels of education attainment correlate with active conceptions of citizenship, and mid-levels of education correlate with state-led conceptions. Higher levels of education do support more active conceptions of citizenship, but that low and middle levels support state-led conceptions of citizenship.

The study's findings suggest that citizenship education at the tertiary level, and more broadly, more years of education does not lead to greater support for the Party, or more oriented towards a socialist notion of citizenship. Or stated differently, tertiary education has a weak effect on notions of socialist citizenship. Granted, it should be acknowledged that the notion of state-driven citizenship is all encompassing and is not merely support for the Party, rather it may overlap with the other components of suzhi and legal notions of citizenship. If these students are more persuaded by active conceptions of citizenship, the Party would be better served by investing in expanding volunteering and service-learning opportunities, instead of redesigning the curriculum. These opportunities have been popular with university students. ${ }^{80}$ This focus would mean that Xi Jinping should empower organizations like the China Youth League rather than continuing efforts to reduce its autonomy and funding. ${ }^{81}$

The broader implication of our findings is that the agenda of constructing contemporary citizens, underway in many authoritarian regimes, will only be effective if concentrated on citizens with less educational attainment. The authoritarian leader's dilemma is that higher education is necessary in a global marketplace as nations move up the value chain; thus, education becomes a double-edged sword. Namely, as China grows out of the middle-income trap, it will inevitably require more educated workers. This will present an increased challenge to a state-led conception of citizenship.

\footnotetext{
${ }^{80}$ Doyon, 'Low-cost corporatism'.

${ }^{81}$ Central Communist Youth League (Gongqingtuan zhongyang), 'Gongqingtuan zhongyang gaige fang'an (Proposal on the reform of the central youth league)', August 2, 2016.
} 


\section{Acknowledgments}

The authors are grateful for the feedback received on an earlier version of this article presented at the Asia Research Institute, National University of Singapore, and Department of Government, Harvard University. We are thankful to Alyssa Suhm and Emma Johns for their valuable research assistance. This project is supported by the University of Alberta's Faculty of Arts and China Institute Research Grants; Colgate University's Research Council; and, the London School of Economics and Political Science's Titmuss Meinhardt Research Grant.

\section{Disclosure Statement}

No potential conflict of interest was reported by the author(s).

\section{Notes on contributors}

Carolyn L. Hsu holds the position of Professor of Sociology at Colgate University in Hamilton, New York. She is the author of Social Entrepreneurship in China (Routledge, 2017) and Creating Market Socialism (Duke UP, 2007), as well as articles in The China Quarterly, Voluntas, Sociological Quarterly, China Information, and Journal of Civil Society, among others. Her research interests include Chinese civil society, citizenship, NGOs, social movements and activism, social credit system, social entrepreneurship, institutions and organizations, social mobility and inequality, and narrative analysis.

Jessica C. Teets is an Associate Professor in the Political Science Department at Middlebury College, the President of the Association of Chinese Studies, and Associate Editor-in-Chief of the Journal of Chinese Political Science. Her research focuses on governance in authoritarian regimes, especially sources of change such as local policy experimentation and civil society. She is the author of Civil Society Under Authoritarianism: The China Model (Cambridge UP, 2014) and editor (with William Hurst) of Local Governance Innovation in China: Experimentation, Diffusion, and Defiance (Routledge, 2014), in addition to articles published in The China Quarterly, World Politics, Governance, and the Journal of Contemporary China. Dr. Teets is a fellow with the Public Intellectuals Program created by the National Committee on United StatesChina Relations (NCUSCR), and is currently researching changing local governance under Xi Jinping.

Reza Hasmath (Ph.D., Cambridge) is a Full Professor in Political Science at the University of Alberta. He has previously held faculty positions in management, sociology and political science at the Universities of Toronto, Melbourne and Oxford, and has worked for think-tanks, consultancies, development agencies, and NGOs in USA, Canada, Australia, UK and China. His award-winning research looks at evolving state-society relationships in authoritarian contexts, with an emphasis on China and NGO activities.

Jennifer Y. J. Hsu is a Research Fellow at the Lowy Institute. She is also a Visiting Fellow in the Social Policy Research Centre, University of New South Wales. Jennifer's research is primarily focused on relations between state and nongovernmental organisations (NGOs) in China, particularly the scope of interactions between the local state and NGOs. Within this research program, she has sought to locate her research in several interdisciplinary domains: theories of state-society relations, organisational development of NGOs and civil society, the internationalisation of Chinese NGOs and overseas Chinese communities. The different areas of her research enhance our theoretical understanding of how state and society engage under varying socio-political environments. Her monograph: State of Exchange: Migrant NGOs and the Chinese Government (UBC Press, 2017) details the importance of the local state in NGO development.

Timothy Hildebrandt is an Associate Professor of Social Policy and Development at the London School of Economics and Political Science. Trained as a political scientist, his areas of expertise include state-society relations, Chinese politics, political communication, civil society, public health, sexuality, and social policy. He is author of Social Organisations and the Authoritarian State in China (Cambridge UP, 2013). His research has appeared in various academic journals including BMJ Open, Journal of Civil Society, Journal of Homosexuality, China Quarterly, Journal of Contemporary China, Review of International Studies, Voluntas, Development \& Change, Foreign Policy Analysis, and Development Policy Review. Tim is also frequently interviewed by media outlets around the world, including BBC, CNN, The Guardian, South China Morning Post, among others. 
Table A1. Affirmative respondents to 'do you participate in volunteer activities?'

\begin{tabular}{lcccccc}
\hline $\begin{array}{l}\text { Level of Education } \\
\text { (Base Response: Low Education }\end{array}$ & $\begin{array}{c}\text { Coefficient } \\
\text { (Unweighted) }\end{array}$ & $\begin{array}{c}\text { Odds } \\
\text { Ratio }\end{array}$ & $\begin{array}{c}\text { Std. } \\
\text { Err. }\end{array}$ & $\begin{array}{c}\text { Coefficient } \\
\text { (Weighted) }\end{array}$ & $\begin{array}{c}\text { Odds } \\
\text { Ratio }\end{array}$ & $\begin{array}{c}\text { Std. } \\
\text { Err. }\end{array}$ \\
\hline Mid Education Group & $0.46^{*}$ & 1.59 & 0.22 & $0.43^{* * *}$ & 1.53 & 0.07 \\
High Education Group & $1.36^{* *}$ & 3.90 & 0.20 & $1.42^{* * *}$ & 4.15 & 0.09 \\
\hline
\end{tabular}

${ }^{*} p<0.05,{ }^{* *} p<0.01$, and ${ }^{* * *} p<0.001$.

Table A2. Affirmative respondents to 'does the government provide sufficient help to disadvantaged groups?'

\begin{tabular}{lcccccc}
\hline $\begin{array}{l}\text { Level of Education } \\
\text { (Base Response: Low Education }\end{array}$ & $\begin{array}{c}\text { Coefficient } \\
\text { (Unweighted) }\end{array}$ & $\begin{array}{c}\text { Odds } \\
\text { Ratio }\end{array}$ & $\begin{array}{c}\text { Std. } \\
\text { Err. }\end{array}$ & $\begin{array}{c}\text { Coefficient } \\
\text { (Weighted) }\end{array}$ & $\begin{array}{c}\text { Odds } \\
\text { Ratio }\end{array}$ & $\begin{array}{c}\text { Std. } \\
\text { Err. }\end{array}$ \\
\hline Mid Education Group & -0.14 & 0.87 & 0.21 & -0.12 & 0.89 & 0.07 \\
High Education Group & $-0.52^{* *}$ & 0.59 & 0.19 & $-0.40^{* * *}$ & 0.67 & 0.08 \\
\hline
\end{tabular}

${ }^{*} p<0.05,{ }^{* *} p<0.01$, and ${ }^{* * *} p<0.001$.

Table A3. Linear regression analysis of 'what areas does the government need help from social organizations?'

\begin{tabular}{|c|c|c|c|c|c|}
\hline Response Option & $\begin{array}{c}\text { Level of Education } \\
\text { (Base Response: Low Education } \\
\text { Group) }\end{array}$ & $\begin{array}{l}\text { Coefficient } \\
\text { (Unweighted) }\end{array}$ & $\begin{array}{l}\text { Std. } \\
\text { Err. }\end{array}$ & $\begin{array}{l}\text { Coefficient } \\
\text { (Weighted) }\end{array}$ & $\begin{array}{l}\text { Std. } \\
\text { Err. }\end{array}$ \\
\hline \multirow[t]{2}{*}{ Environment } & Mid Education Group & 0.13 & 0.11 & $0.09 *$ & 0.04 \\
\hline & High Education Group & $0.19 *$ & 0.10 & $0.14 * *$ & 0.05 \\
\hline \multirow[t]{2}{*}{ LGBTQ Issues } & Mid Education Group & 0.19 & 0.13 & $0.12 *$ & 0.05 \\
\hline & High Education Group & $0.25 *$ & 0.12 & $0.18 * *$ & 0.05 \\
\hline \multirow[t]{2}{*}{ Healthcare } & Mid Education Group & 0.17 & 0.10 & $0.16^{* * *}$ & 0.04 \\
\hline & High Education Group & $0.30 * *$ & 0.09 & $0.32 * * *$ & 0.05 \\
\hline \multirow[t]{2}{*}{ Legal Services } & Mid Education Group & 0.04 & 0.10 & 0.04 & 0.04 \\
\hline & High Education Group & 0.17 & 0.09 & $0.21 * * *$ & 0.04 \\
\hline \multirow[t]{2}{*}{ Disabilities } & Mid Education Group & 0.11 & 0.10 & $0.10 *$ & 0.04 \\
\hline & High Education Group & 0.16 & 0.09 & $0.20 * * *$ & 0.04 \\
\hline \multirow[t]{2}{*}{ Tourism } & Mid Education Group & 0.06 & 0.12 & 0.02 & 0.05 \\
\hline & High Education Group & 0.08 & 0.11 & 0.08 & 0.05 \\
\hline \multirow[t]{2}{*}{ Public Safety } & Mid Education Group & 0.05 & 0.10 & $0.08 *$ & 0.04 \\
\hline & High Education Group & 0.08 & 0.09 & $0.15 * *$ & 0.15 \\
\hline \multirow{2}{*}{$\begin{array}{l}\text { Disaster/Emergency } \\
\text { Response }\end{array}$} & Mid Education Group & 0.05 & 0.10 & 0.04 & 0.04 \\
\hline & High Education Group & $0.21 *$ & 0.09 & $0.17 * * *$ & 0.04 \\
\hline \multirow[t]{2}{*}{ Monitoring Business } & Mid Education Group & 0.17 & 0.12 & $0.13 * *$ & 0.04 \\
\hline & High Education Group & 0.14 & 0.11 & 0.07 & 0.05 \\
\hline \multirow[t]{2}{*}{ Poverty } & Mid Education Group & 0.08 & 0.10 & $0.09 *$ & 0.04 \\
\hline & High Education Group & $0.18 *$ & 0.09 & $0.17^{* * *}$ & 0.05 \\
\hline \multirow[t]{2}{*}{ Women's Rights } & Mid Education Group & 0.18 & 0.12 & $0.15 * *$ & 0.05 \\
\hline & High Education Group & 0.17 & 0.11 & $0.14 * *$ & 0.05 \\
\hline
\end{tabular}

${ }^{*} p<0.05,{ }^{* *} p<0.01$, and ${ }^{* * *} p<0.001$. 